medRxiv preprint doi: https://doi.org/10.1101/2021.01.12.21249152; this version posted January 13, 2021. The copyright holder for this preprint (which was not certified by peer review) is the author/funder, who has granted medRxiv a license to display the preprint in perpetuity.

All rights reserved. No reuse allowed without permission.

\title{
Predictors of COVID-19 Vaccine Hesitancy: Socio-demographics, Co-Morbidity and Past Experience of Racial Discrimination
}

Savoia E. ${ }^{1}$ MD, MPH, Piltch-Loeb R. ${ }^{1}$ PhD, MSPH, Goldberg B. MA, MBA ${ }^{2}$, Miller-Idriss C. ${ }^{3}$ PhD, Hughes B. PhD, ${ }^{3}$ Montrond AM. ${ }^{1}$ MA, Kayyem JN. JD, ${ }^{4}$ Testa MA. ${ }^{1}$ PhD, MPH

${ }^{1}$ Emergency Preparedness Research Evaluation \& Practice (EPREP) Program, Division of Policy Translation \& Leadership Development, Harvard T.H. Chan School of Public Health, Boston, MA

${ }^{2}$ Jigsaw, Google LLC, New York, NY

${ }^{3}$ Center for University Excellence (CUE) and Polarization and Extremism Research and Innovation Lab (PERIL), American University, Washington, DC

${ }^{4}$ Harvard Kennedy School, Harvard University, Cambridge, MA

Authors' contribution: Dr. Savoia conceived the study, conducted data analysis and drafted the manuscript. Dr. Piltch-Loeb developed the survey instrument, oversaw data collection and provided feedback during the development of the manuscript. Ms. Goldberg, Dr. Miller-Idriss and Dr. Hughes participated in all study phases, contributed to the development of the survey questions and interpretation of findings. Mr. Montrond contributed to the conceptualization of the study goals, provided feedback during the development of the survey instrument and drafted the discussion. Dr. Kayyem provided substantial comments during the development of the manuscript. Dr. Testa oversaw data analysis and contributed to the interpretation of study findings.

\section{Introduction}

Within a year, the SARS-CoV-2 pandemic spread worldwide infecting millions of individuals and causing thousands of deaths. Under the federal Operation Warp Speed program, administered by the U.S. Department of Health and Human Services, $\$ 10$ billion dollars were invested in six candidate vaccines. ${ }^{1}$ In November 2020, Pfizer-BioNTech ${ }^{2}$ and Moderna ${ }^{3}$ reported that their much-anticipated vaccines demonstrated over $90 \%$ effectiveness in protecting people from the disease. Both vaccines were developed and tested at record speed and given U.S. Food and Drug Administration (FDA) emergency use authorization (EUA) in December 2020. ${ }^{4,5}$ Vaccine distribution of the Pfizer/BioNTech vaccine began on December 8 2020, starting from a 90 year-old grandmother in Great Britain. Two months prior to the approval of the vaccines, the 
medRxiv preprint doi: https://doi.org/10.1101/2021.01.12.21249152; this version posted January 13, 2021. The copyright holder for this preprint (which was not certified by peer review) is the author/funder, who has granted medRxiv a license to display the preprint in perpetuity.

All rights reserved. No reuse allowed without permission.

Centers for Disease Control and Prevention (CDC) released its interim playbook for jurisdictional operations outlining a phased approach to COVID-19 vaccination starting from those considered most at risk due to their job, age and health status. ${ }^{6}$

While in some ways the difficult scientific efforts in producing the vaccine have proven so successful, the delivery of the vaccine to the public is expected to face vast logistical, distribution and information systems challenges. Along with organizational aspects, hesitancy of individuals to take the vaccine is also a formidable challenge. Immunization programs are only successful when there are high rates of acceptance and coverage. Addressing vaccine hesitancy, while delivering billions of doses across the world will be one of the greatest public health risk communication efforts ever undertaken. As such, it is critical to understand the reasons why specific segments of the population are more hesitant than others to accept the vaccination, and address the reasons of such hesitancy to the extent possible when implementing distribution plans. $^{7}$

Various opinion polls have identified high levels of vaccine skepticism and specific reasons for such skepticism. Kreps and colleagues ${ }^{8}$ found that vaccine efficacy and safety are important factors associated with public acceptance of a COVID-19 vaccine, as well as the process by which a vaccine is authorized and by whom it is endorsed. A survey of a representative sample of the U.S. population, conducted in May 2020, prior to the release of the Pfizer-BioNTech and Moderna vaccines, reported that 33\% of the population was vaccine hesitant and that in particular Black respondents were less likely to accept a potential COVID-19 vaccine. ${ }^{9}$ These results are fairly similar across polls, with some variation depending on the time the poll was conducted and the socio-demographics, co-morbidity characteristics of the sampled population. According to a recent longitudinal probability-based internet survey of the US 
population the likelihood of getting a COVID-19 vaccine declined from $74 \%$ in early April to $56 \%$ in early December $2020^{10}$. A more recent poll showed that $35 \%$ of Black respondents are hesitant about receiving the vaccine, $71 \%$ of which say they are worried about possible side effects, and $50 \%$ believe that they can become infected with COVID-19 from the vaccination. ${ }^{11}$ This low acceptance is consistent with historical disparities in influenza immunization behavior and perceptions in the U.S. population, with Black adults significantly less likely to receive the influenza vaccine than White adults. ${ }^{12,13}$ This is particularly concerning considering that Black individuals shoulder a disproportionate burden of many chronic conditions, placing them at higher risk for complications from preventable diseases like influenza ${ }^{14}$, and now that vaccines are available, from COVID-19 as well. Research on the racial disparities in influenza immunization rates in the general population have identified several psychosocial and behavioral factors associated with vaccine uptake including: perceived risk, trust, vaccine attitudes, social norms, and experiences of racism. ${ }^{15}$ The goal of this study is to explore the predictors of COVID-19 vaccine hesitancy including socio-demographic factors, co-morbidity, risk perception and past-experience with discrimination, in particular among those identified as priority groups for the vaccination. The study is based on a rapid survey conducted around the time of the PfizerBioNTech and Moderna vaccines approval with the ultimate goal of informing public officials on how to enhance vaccine communication efforts during the vaccination campaign.

\section{Methods}

Study Design 
medRxiv preprint doi: https://doi.org/10.1101/2021.01.12.21249152; this version posted January 13, 2021. The copyright holder for this preprint (which was not certified by peer review) is the author/funder, who has granted medRxiv a license to display the preprint in perpetuity.

All rights reserved. No reuse allowed without permission.

We used a cross-sectional online survey study design. The survey was implemented via mobile phones by the use of the survey platform Pollfish, and it was limited to respondents over 18 years of age residing in the USA. Similar to third-party advertising companies, Pollfish pays mobile application developers to display and promote the surveys to their users. To incentivize participation, relatively small monetary reimbursements are provided to randomly selected users who complete the surveys. An initial survey instrument draft was implemented for cognitive testing with 20 individuals, and the survey was subsequently revised after feedback to include 36 questions. Questions and response choices were kept short using "yes/no" or Likert-type and rating scales to facilitate completion by the use of mobile phones. The survey was launched on December 13 and closed on December 23, 2020. A screening question was used to identify respondents belonging to one of 19 job categories that were identified as priority groups for vaccine distribution based on national guidance available at the time of the survey. ${ }^{16}$ The study protocol and survey instrument were approved by the Harvard T.H. Chan School of Public Health Institutional Review Board. A copy of the survey instrument can be found in Appendix.

\section{Dependent Variable}

Multivariable ordinal regression was undertaken to model the underlying construct of vaccine hesitancy measured by the creation of a Likert-type scale. Respondents were asked how likely they would be to take a COVID-19 vaccine if offered to them at no cost within two months. Answer options were ordered as follows: very likely (1), somewhat likely (2), would consider it after two months (3), not sure (4), somewhat unlikely (5), very unlikely (6). Results were interpreted with a range of values from 1 (low hesitancy) to 6 (high hesitancy).

\section{Independent Variables}


medRxiv preprint doi: https://doi.org/10.1101/2021.01.12.21249152; this version posted January 13, 2021. The copyright holder for this preprint (which was not certified by peer review) is the author/funder, who has granted medRxiv a license to display the preprint in perpetuity.

All rights reserved. No reuse allowed without permission.

Independent predictor variables included socio-demographics such as age, gender, race, level of education and employment status. Other predictors included job type (working in the healthcare sector versus other priority groups for vaccination), having had a diagnosis of COVID-19 (with no symptoms, mild or severe symptoms), clinical risk of severe consequences from COVID-19, risk perception of contracting the disease or infecting others, and past experience with discrimination. Risk perception was measured by asking respondents to report their level of concern with contracting COVID-19 at work, outside their work environment, and infecting family members or friends. A factor analysis was performed to assess the structure of the risk perception questions, and as a result a scale was created with scores ranging from 0 to 6 , with lower values indicating lower risk perception. Kaiser-Meyer-Olkin (KMO) measure of sampling adequacy was used to test for the suitability of the data for factor analysis and Cronbach's alpha to assess the reliability of the scale. The respondents' clinical risk for severe consequences from COVID-19 was measured by asking about the underlying health conditions most frequently associated with severe disease or death (diabetes, cardiovascular disease, obesity, pulmonary disease, immunocompromised status, rheumatological condition, or cancer), responses were converted into a dichotomous variable describing presence of at least one comorbidity versus absence of comorbidities. Finally, respondents were asked about past experience with unfair treatment they attributed to their race, religion, gender or sexual orientation using an adaptation of the discrimination scale developed by Sternthal, M.J. et al. ${ }^{17}$ This scale includes six questions on unfair treatment experienced in the work environment, at school, by a police officer and by financial institutions (i.e. bank loan). The adaptation consisted of adding a question about unfair treatment by a physician or nurse and by limiting the cause of the unfair treatment to race, religion, gender, and sexual orientation. 
medRxiv preprint doi: https://doi.org/10.1101/2021.01.12.21249152; this version posted January 13, 2021. The copyright holder for this preprint (which was not certified by peer review) is the author/funder, who has granted medRxiv a license to display the preprint in perpetuity.

All rights reserved. No reuse allowed without permission.

\section{Statistical Analyses}

We first performed descriptive statistics for each variable. We then applied simple and multiple ordinal regression models to study the association between the independent variables and COVID-19 vaccine hesitancy (dependent variable). We tested for bivariate associations between each predictor [age, gender, race, education, employment status, job type, having had a diagnosis of COVID-19, clinical risk profile, risk perception and experience of discrimination] and the dependent variable, by means of ordinal and logistic regression using a p-value $<0.05$ as cut-off for inclusion of the independent variables in the multiple regression model. We tested the parallel regression assumption by means of the Brant test for the ordinal logistic model which did not show statistical significance. The Stata Statistical Software 16 was used.

\section{Results}

Socio-demographic characteristics of the study population

Responses were received from 2,650 respondents (response rate 84\%) from all 50 states and the territories of Puerto Rico, American Samoa and Guam. Descriptive statistics are given in Table 1. The five most represented states were California (13\%), New York (10\%), Texas (7\%), Florida (6\%) and Pennsylvania (4\%). Sixty-six percent of respondents were age 25-44 years with median age 37 years, 53\% were male, and $61 \%$ were working in the healthcare sector. The majority of respondents were white and non-Hispanic (66\%) and others were Black nonHispanic (14\%) and Hispanic (8\%). Respondents were highly educated with $31 \%$ having a graduate-level degree, and $86 \%$ were employed at the time of the survey.

Previous COVID-19 diagnosis, clinical risk, and risk perceptions 
medRxiv preprint doi: https://doi.org/10.1101/2021.01.12.21249152; this version posted January 13, 2021. The copyright holder for this preprint (which was not certified by peer review) is the author/funder, who has granted medRxiv a license to display the preprint in perpetuity.

All rights reserved. No reuse allowed without permission.

As shown in Table 2, twenty four percent of the sample respondents reported having had a prior diagnosis of COVID-19, 83\% of whom had no or mild symptoms. Analysis of the clinical risk profile for severe consequences of COVID-19 indicated $26 \%$ of respondents reporting one of the seven conditions associated with greater risk, $5 \%$ reported two and $2 \%$ reported three conditions or more. Fifty-eight percent of respondents were very concerned about getting infected at work, $48 \%$ were very concerned about contracting the disease outside the work environment, and $62 \%$ were very concerned about the possibility of infecting family members or friends. The factor analysis of these three risk perception questions resulted in one factor with eigenvalue $>1$, $\mathrm{KMO}=0.7$, alpha $=0.8$. Based on the factor analysis results, a summative score was created to describe overall risk perception ranging from 0 (low risk) to 6 (high risk), and subsequently three categories of risk perception were created including: low risk perception (up to the 25 th percentile), medium risk perception (25th - $<75$ th percentile) and high-risk perception $(\geq 75$ th percentile). Fifty-five percent of respondents were in the high-risk perception category, $31 \%$ in the medium risk category and $14.5 \%$ in the low risk.

\section{Past experience with discrimination and vaccine hesitancy}

As shown in Table 2, sixty-eight percent of respondents reported having experienced at least once in their lifetime unfair treatment because of their race $(34.5 \%)$, religion (12\%), gender $(21 \%)$, or sexual orientation $(14 \%)$. Experience with unfair treatment due to race was reported by all race groups, $62 \%$ of Black respondents, $50 \%$ of those reporting two or more races, $49 \%$ of Hispanic, $45 \%$ of Asian, and $25 \%$ of white respondents. Experience with unfair treatment due to sexual orientation was reported by $50 \%$ of respondents who did not self-identify either as male or female, $23 \%$ identified as female and $18 \%$ as male. Unfair treatment due to gender was reported by $40 \%$ of those self-identifying as neither male or female, $11 \%$ identifying as female 
medRxiv preprint doi: https://doi.org/10.1101/2021.01.12.21249152; this version posted January 13, 2021. The copyright holder for this preprint (which was not certified by peer review) is the author/funder, who has granted medRxiv a license to display the preprint in perpetuity.

All rights reserved. No reuse allowed without permission.

and $16 \%$ as male. In terms of type of experience Black and Hispanic individuals. and those of two or more races reported the most discrimination. (See Figure 1). Forty percent of the sample reported that they would be very likely to take the COVID-19 vaccine, if offered within two months from the time of the survey. In contrast, $13 \%$ said they were very unlikely to take it. The remaining forty-seven percent expressed various degrees of hesitancy with $15 \%$ responding that they would consider taking the vaccine in the future.

\section{Logistic Regression Models}

Results of the simple and multivariable regressions are shown in Table 3. In the simple regression models (bivariate analysis) several variables were significantly associated with vaccine hesitancy. Female respondents had $25 \%$ decreased odds of reporting a higher level of hesitancy compared to male respondents $(\mathrm{OR}=0.85,95 \%$ C.I. 0.74-0.98). Respondents with some college education had 34\% decreased odds of being at a higher level of hesitancy compared to individuals with less than a high school degree ( $\mathrm{OR}=0.66,95 \%$ C.I. $0.44-0.99)$. Respondents reporting their race as Black and non-Hispanic had 1.22 times the odds of being at a higher level of hesitancy compared to any other race group $(\mathrm{OR}=1.22,95 \%$ C.I. 1.01-1.48). Those with a high-risk perception of contracting COVID-19 or of infecting a family member or friend had 1.30 times the odds of being at a higher level of hesitancy compared to those not having such concerns $(\mathrm{OR}=1.30,95 \%$ C.I. 1.06-1.60). Respondents who had COVID-19 with severe symptoms were more hesitant about taking the vaccine with 1.42 times the odds of being at a higher level of hesitancy compared to those who did not experience the disease at all $(\mathrm{OR}=1.42,95 \%$ C.I 1.01-1.99). Finally, those who experienced unfair treatment attributed to either their race, religion, gender or sexual orientation had 1.19 the odds of being at a higher 
medRxiv preprint doi: https://doi.org/10.1101/2021.01.12.21249152; this version posted January 13, 2021. The copyright holder for this preprint (which was not certified by peer review) is the author/funder, who has granted medRxiv a license to display the preprint in perpetuity.

All rights reserved. No reuse allowed without permission.

level of hesitancy compared to those who did experience discrimination due to the abovementioned reasons $(\mathrm{OR}=1.19,95 \%$ C.I. 1.03-1.37).

When the specific reasons for the perceived discrimination were analyzed as independent variables, racial discrimination was the only variable with a significant association with vaccine hesitancy. Those who experienced racial discrimination had 1.3 times the odds of being at a higher level of hesitancy compared to those who had not reported experiencing this type of discrimination $(\mathrm{OR}=1.30,95 \%$ C.I. 1.12-1.50). (See Figure 1). For the multivariable model, of vaccine hesitancy, the overall LR chi-square test statistics was significant $\left(\chi^{2}, \mathrm{p}<0.01\right)$. Brant test p-value resulted 0.68 .

In the multivariable models, the only variable associated with vaccine hesitancy was experience of racial discrimination Individuals with past experience had $21 \%$ increased odds of being at a higher level of vaccine hesitancy compared to those who did not report such experience. $(\mathrm{OR}=1.21,95 \%$ C.I. $1.01-1.45)$. The most frequently reported racial discrimination situation $r$ was abuse from a police officer (15\%), followed by having been denied a job or unfairly fired (13\%), discouragement in pursuing an education was experienced by $11 \%$ of respondents. While all racial groups reported experience with unfair treatment due to their race, Black and Hispanic respondents and those of two or more races reported this experience most frequently.

\section{Discussion}

COVID-19 vaccine hesitancy is developing in a context in which many are fatigued by the mitigation strategies, seeing them as ineffective, and in some cases even punitive. High acceptance of COVID-19 vaccines is critical to ending the pandemic especially among groups 
medRxiv preprint doi: https://doi.org/10.1101/2021.01.12.21249152; this version posted January 13, 2021. The copyright holder for this preprint (which was not certified by peer review) is the author/funder, who has granted medRxiv a license to display the preprint in perpetuity.

All rights reserved. No reuse allowed without permission.

for which high transmission rates have been recorded. Based on historical immunization data and current survey results, vaccine hesitancy is higher among Black persons compared to White persons. The low likelihood of getting a COVID-19 vaccine among Black persons is especially concerning because of high rates of transmission in Black communities. Policymakers and public health professionals need to start planning now to make sure the vaccine reaches all Americans — and in particular, that people of color belonging to the priority groups for the vaccination, will not record disproportionally low vaccination rates compared to Whites, and that their concerns will be addressed early on. Public information and warning is one of the preparedness capabilities that public health agencies across the country will need to implement to support the vaccination campaign efforts. ${ }^{18}$ This capability entails the implementation of systems and procedures to mobilize communication activities such as fact gathering, rumor control, message testing, monitoring and publishing content across print, Internet, social, and other media and providing support to spoke persons, such as developing talking points, speeches, and visuals. The results from our study emphasize the need to potentiate monitoring strategies, so to gather information from the public on concerns and reasons for hesitancy towards the COVID-19 vaccine to better target communication efforts to individuals' informational needs, concerns and experiences. This study has the advantage of focusing on individuals belonging to priority groups to receive the vaccine. This is important as a successful vaccination campaign must demonstrate initial acceptance by the first to be vaccinated. Early adopters of immunization can have a strong influence on the likelihood that others will accept the vaccine and will be compliant with the immunization recommendations. In particular, our sample includes a large fraction of individuals working in the healthcare sector who could be key actors in advocating for the vaccine among the general population. To our knowledge our study is the first to date to 
medRxiv preprint doi: https://doi.org/10.1101/2021.01.12.21249152; this version posted January 13, 2021. The copyright holder for this preprint (which was not certified by peer review) is the author/funder, who has granted medRxiv a license to display the preprint in perpetuity.

All rights reserved. No reuse allowed without permission.

include a measure of past experience of discrimination as a predictor of COVID-19 vaccine hesitancy, enriching current knowledge on the relationship vaccine hesitancy and race identified by previous studies. The results show that past-experience of discrimination is a predictor of vaccine hesitancy. This result is important to inform communication and logistical aspects of the COVID-19 vaccination campaign. During the short timeframe of this vaccination campaign, even with the best of intentions, policy makers and public health practitioners will not be able to undo centuries of distrust based on unfair treatment experienced by specific segments of the population in health care, education, finance, and safety. However, they can be sensitive to historical and individuals' experiences by identifying trusted places and sources of COVID-19 vaccine information and distribution, they can educate clinicians and spokesperson on historical facts, avoiding use of law enforcement to surveil the safety of vaccination sites, engaging individuals from Black communities in vaccination efforts and educating policy makers and vaccine distribution planners on the root causes of mistrust. Enhancing uptake among Black Americans requires much more than disseminating facts about safety - it requires overcoming barriers of mistrust in the system. Policy makers and public officials need to start by acknowledging, appreciating, and discussing mistrust. Labeling those hesitant about the vaccine as conspiracy theorists or individuals unwilling to prevent the spread of the disease, may be counterproductive when hesitancy is rooted in a history of unfair treatment which will not be overturned by denying the existence of fear and doubts. When addressing safety in regards to the COVID-19 vaccine, the content of the message should go beyond the safety of the vaccine per se, and include explicit references and historical comparisons of why this vaccination campaign will not cause another Tuskegee Study. Bidirectional risk communication is of particular importance when one of the goals of the mitigation strategy is to reduce health disparities. 
medRxiv preprint doi: https://doi.org/10.1101/2021.01.12.21249152; this version posted January 13, 2021. The copyright holder for this preprint (which was not certified by peer review) is the author/funder, who has granted medRxiv a license to display the preprint in perpetuity.

All rights reserved. No reuse allowed without permission.

Previous studies have demonstrated the presence of communication inequalities, consisting of inequalities in individual or group specific exposure and reactions to public health communication messages, ${ }^{19,20,21}$ which may lead to further enhance existing disparities across segments of the population in the ability to comply with recommended preventive behaviors. Opinion surveys, at the time of crisis, are a tool to understand people's concerns so that such concerns can be addressed in communication efforts. ${ }^{22}$ In the case of COVID-19, public officials will need to develop bidirectional communication strategies so that they effectively communicate the correct information concerning the vaccine's risks and benefits while listening to public opinions and concerns. They also need to be aware that public concerns are not only related to direct health risks due to potential adverse effects from the immunization, but they are also linked to personal beliefs, cultural perspectives and ideology. These concerns are currently further fueled by an emotional dimension driven by the social isolation and daily life restrictions and difficulties brought on by the pandemic. Public health agencies need to enhance their public information capabilities to address multiple dimensions of the vaccine communication strategy in order to be successful and meet growing needs of information, reassurance and address mistrust to the extent possible.

\section{Study Limitations}

Because we used a cross sectional study design, the timing of the survey must be considered in interpreting and generalizing the results. The survey was fielded in December 2020 when vaccines were announced but not yet available to the public. Due to the evolving epidemiology of the disease, and developing public communication and vaccine distribution efforts the predictors of vaccine hesitancy are likely to change overtime, in particular in regards to the impact of some independent variables for which, in our study, we did not find a statistical 
medRxiv preprint doi: https://doi.org/10.1101/2021.01.12.21249152; this version posted January 13, 2021. The copyright holder for this preprint (which was not certified by peer review) is the author/funder, who has granted medRxiv a license to display the preprint in perpetuity.

All rights reserved. No reuse allowed without permission.

significant association with vaccine hesitancy such as risk perception of contracting COVID-19. Our sample is not a representative sample of the US population as such study results are not generalizable outside the study population. While our sample included a distribution of racialethnic groups that allowed us to analyze predictors of vaccine hesitancy based on race it did not include a sufficient number of individuals over 65 which based on previous studies are more likely than others to accept the COVID-19 vaccine due the increased risk of severity in the elderly.

\section{Conclusions}

Results from this survey of a convenience sample of the US population show that past experience with discrimination is a predictor of vaccine hesitancy. This result is important to inform communication and logistical aspects during the COVID-19 vaccination campaign which need to be sensitive to individuals' past experience with systemic unfair treatment by different types of institutions including law enforcement, education and healthcare. 
medRxiv preprint doi: https://doi.org/10.1101/2021.01.12.21249152; this version posted January 13, 2021. The copyright holder for this preprint (which was not certified by peer review) is the author/funder, who has granted medRxiv a license to display the preprint in perpetuity. All rights reserved. No reuse allowed without permission.

Table 1. Socio-demographic characteristics of the study population

\begin{tabular}{|l|l|}
\hline Age & $\mathrm{N}(\%)$ \\
\hline $18-24$ & $354(13.4 \%)$ \\
\hline $25-34$ & $841(31.7 \%)$ \\
\hline $35-44$ & $906(34.2 \%)$ \\
\hline $45-54$ & $339(12.8 \%)$ \\
\hline $55-64$ & $152(5.7 \%)$ \\
\hline $65-74$ & $47(1.8 \%)$ \\
\hline$\geq 75$ & $11(0.4 \%)$ \\
\hline Gender & $\mathrm{N}(\%)$ \\
\hline Male & $1417(53.5 \%)$ \\
\hline Female & $1213(45.8 \%)$ \\
\hline Other & $20(0.7 \%)$ \\
\hline Education & $\mathrm{N}(\%)$ \\
\hline Less than high school & $92(3.2 \%)$ \\
\hline High school/GED & $539(20.3 \%)$ \\
\hline Some college & $579(21.9 \%)$ \\
\hline Bachelor's degree & $615(23.3 \%)$ \\
\hline Post-graduate degree & $825(31.3 \%)$ \\
\hline Race & \\
\hline White, non-Hispanic & $1754(66.2 \%)$ \\
\hline Black, non-Hispanic & $379(14.3 \%)$ \\
\hline Hispanic & $206(7.8 \%)$ \\
\hline Asian, non-Hispanic & $130(4.9 \%)$ \\
\hline 2+ races & $122(4.6 \%)$ \\
\hline Prefer not to say & $40(1.5 \%)$ \\
\hline Other & $19(0.7 \%)$ \\
\hline Employment status & $\mathrm{N}(\%)$ \\
\hline Paid employee & $2032(76.7 \%)$ \\
\hline Self-employed & $243(9.2 \%)$ \\
\hline On unemployment & $101(3.8 \%)$ \\
\hline Not working - searching for work & $96(3.6 \%)$ \\
\hline On paid leave or furloughed & $41(1.6 \%)$ \\
\hline Retired & $41(1.6 \%)$ \\
\hline Not working - and not looking for a job & $39(1.4 \%)$ \\
\hline On disability or worker's compensation & $35(1.3 \%)$ \\
\hline Other & $22(0.8 \%)$ \\
\hline Job category (multiple choice question) & $\mathrm{N}(\%)$ \\
\hline Hospital and emergency department workers & $624(23.5 \%)$ \\
\hline Nursing home, long-term care, and home health care workers & $413(15.6 \%)$ \\
\hline Public health workers & $284(10.7 \%)$ \\
\hline Grocery store workers & $283(10.7 \%)$ \\
Teachers and school staff & $251(9.5 \%)$ \\
\hline & \\
\hline
\end{tabular}




\begin{tabular}{|l|l|}
\hline Food processing workers & $222(8.4 \%)$ \\
Emergency Medical Services workers & $186(7.0 \%)$ \\
Other health care workers & $170(6.4 \%)$ \\
Volunteer (i.e. CERT, MRC, Red Cross, etc.) & $168(6.3 \%)$ \\
Private transportation workers & $156(5.9 \%)$ \\
Sanitation workers & $131(4.9 \%)$ \\
Vaccine manufacturing workers & $121(4.6 \%)$ \\
Postal and shipping workers & $120(4.5 \%)$ \\
Pharmacy workers & $117(4.4 \%)$ \\
Correctional facilities workers & $116(4.4 \%)$ \\
Police or firefighters & $116(4.4 \%)$ \\
Vaccine distribution workers & $95(3.6 \%)$ \\
Other first responders & $93(3.5 \%)$ \\
Public transportation workers & $90(3.4 \%)$ \\
\hline
\end{tabular}

Table 2. Comorbidity, risk perception, experience of discrimination and vaccine hesitancy of the study population

\begin{tabular}{|c|c|}
\hline $\begin{array}{l}\text { Co-morbidity [diabetes, obesity, rheumatological disease, } \\
\text { immunocompromised status, cancer, cardiovascular disease, } \\
\text { chronic respiratory disease]. }\end{array}$ & $\mathrm{N}(\%)$ \\
\hline No medical condition & $1764(66.6 \%)$ \\
\hline One medical condition & $685(25.8 \%)$ \\
\hline Two or more medical conditions & $201(7.6 \%)$ \\
\hline Have you been diagnosed with COVID-19? & $\mathrm{N}(\%)$ \\
\hline $\begin{array}{l}\text { No } \\
\text { I am not sure } \\
\text { Yes, with no symptoms } \\
\text { Yes, with mild symptoms } \\
\text { Yes, with severe symptoms }\end{array}$ & $\begin{array}{l}1961(74 \%) \\
57(2.2 \%) \\
266(10 \%) \\
259(9.8 \%) \\
107(4 \%)\end{array}$ \\
\hline Experience of unfair treatment & $\mathrm{N}(\%)$ \\
\hline $\begin{array}{l}\text { Attributed to any of the following reasons: race, religion, gender } \\
\text { and sexual orientation }\end{array}$ & $1680(63.4 \%)$ \\
\hline Race was the only reason or one of the reasons & $915(34.5 \%)$ \\
\hline Religion was the only reason or one of the reasons & $318(12 \%)$ \\
\hline Gender was the only reason or one of the reasons & $549(20.7 \%)$ \\
\hline Sexual orientation was the only reason or one of the reasons & $361(13.6 \%)$ \\
\hline How concerned are you about any of the following situations? & $\mathrm{N}(\%)$ \\
\hline \multicolumn{2}{|c|}{$\begin{array}{l}\text { Contracting COVID-19 at work? (For example: hospital, office, and other work settings that } \\
\text { are not your home) }\end{array}$} \\
\hline $\begin{array}{l}\text { Very concerned } \\
\text { Somewhat concerned } \\
\text { Not concerned }\end{array}$ & $\begin{array}{l}1542(58.3 \%) \\
792(29.9 \%) \\
312(11.8 \%) \\
\end{array}$ \\
\hline
\end{tabular}


medRxiv preprint doi: https://doi.org/10.1101/2021.01.12.21249152; this version posted January 13, 2021. The copyright holder for this preprint (which was not certified by peer review) is the author/funder, who has granted medRxiv a license to display the preprint in perpetuity.

using transportation, or in other aspects of your daily life)

\begin{tabular}{|c|c|}
\hline $\begin{array}{l}\text { Very concerned } \\
\text { Somewhat concerned } \\
\text { Not concerned }\end{array}$ & $\begin{array}{l}1266(47.9 \%) \\
1007(38.1 \%) \\
371(14 \%) \\
\end{array}$ \\
\hline \multicolumn{2}{|l|}{ Infecting your family or friends with COVID-19? } \\
\hline $\begin{array}{l}\text { Very concerned } \\
\text { Somewhat concerned } \\
\text { Not concerned }\end{array}$ & $\begin{array}{l}1653(62.5 \%) \\
664(25.1 \%) \\
326(12.4 \%) \\
\end{array}$ \\
\hline COVID-19 overall risk perception & $\mathrm{N}(\%)$ \\
\hline $\begin{array}{l}\text { Low risk } \\
\text { Medium risk } \\
\text { High risk }\end{array}$ & $\begin{array}{l}382(14.5 \%) \\
813(30.1 \%) \\
1439(54.6 \%) \\
\end{array}$ \\
\hline $\begin{array}{l}\text { If you were offered a COVID-19 vaccine within two months from } \\
\text { now - at no cost to you- how likely are you to take it? }\end{array}$ & $\mathrm{N}(\%)$ \\
\hline $\begin{array}{l}\text { Very likely [low hesitancy] } \\
\text { Somewhat likely } \\
\text { I would not take it within } 2 \text { months but would consider it later on } \\
\text { Not sure } \\
\text { Somewhat unlikely } \\
\text { Very unlikely [high hesitancy] }\end{array}$ & $\begin{array}{l}1059(40 \%) \\
523(19.7 \%) \\
188(7.1 \%) \\
388(14.6 \%) \\
153(5.8 \%) \\
339(12.8 \%)\end{array}$ \\
\hline
\end{tabular}

Table 3. Association between independent variables and vaccine hesitancy: simple models and multiple variable models

\begin{tabular}{|c|c|c|c|c|}
\hline \multirow[b]{2}{*}{$\begin{array}{l}\text { Independent } \\
\text { variable }\end{array}$} & \multicolumn{2}{|c|}{ Simple models } & \multicolumn{2}{|c|}{ Multiple model } \\
\hline & OR & 95\% C.I. & OR & 95\% C.I. \\
\hline \multicolumn{5}{|l|}{ Age } \\
\hline $18-24$ & - & - & - & - \\
\hline $25-34$ & 1.07 & $0.86-1.34$ & - & - \\
\hline $35-44$ & 0.99 & $0.80-1.24$ & - & - \\
\hline $45-54$ & 1.03 & $0.79-1.35$ & - & - \\
\hline $55-64$ & 0.97 & $0.69-1.36$ & - & - \\
\hline $65-74$ & 0.75 & $0.43-1.32$ & - & - \\
\hline$\geq 75$ & 1.16 & $0.41-3.24$ & - & - \\
\hline \multicolumn{5}{|l|}{ Gender } \\
\hline $\begin{array}{l}\text { Female versus male } \\
\text { Other than female or } \\
\text { male versus male }\end{array}$ & $\begin{array}{l}0.85 * \\
0.59\end{array}$ & $\begin{array}{l}0.74-0.98 \\
0.26-1.33\end{array}$ & $\begin{array}{l}0.91 \\
0.62\end{array}$ & $\begin{array}{l}0.78-1.05 \\
0.27-1.42\end{array}$ \\
\hline
\end{tabular}




\begin{tabular}{|c|c|c|c|c|}
\hline \multicolumn{3}{|l|}{ Employment status } & \multirow[b]{2}{*}{-} & \multirow[b]{2}{*}{-} \\
\hline $\begin{array}{l}\text { Paid employee and } \\
\text { self-employed versus } \\
\text { other categories }\end{array}$ & 1.14 & $0.94-1.39$ & & \\
\hline \multicolumn{5}{|l|}{ Education } \\
\hline Less than high school & - & - & - & - \\
\hline High school/GED & 0.78 & $0.52-1.15$ & 0.78 & $0.52-1.17$ \\
\hline Some college & $0.66^{*}$ & $0.44-0.99$ & 0.68 & $0.45-1.01$ \\
\hline Bachelor's degree & 0.77 & $0.52-1.13$ & 0.78 & $0.52-1.16$ \\
\hline Post-graduate degree & 0.97 & $0.66-1.43$ & 0.95 & $0.64-1.40$ \\
\hline \multicolumn{5}{|l|}{ Race } \\
\hline $\begin{array}{l}\text { White non-Hispanic } \\
\text { versus all other races }\end{array}$ & 0.94 & $0.81-1.1$ & - & - \\
\hline $\begin{array}{l}\text { Black non-Hispanic } \\
\text { versus all other races }\end{array}$ & $1.22 *$ & $1.00-1.48$ & 1.18 & $0.96-1.44$ \\
\hline $\begin{array}{l}\text { Asian non-Hispanic } \\
\text { versus all other races }\end{array}$ & 0.87 & $0.63-1.20$ & - & - \\
\hline $\begin{array}{l}\text { Hispanic versus all } \\
\text { other races }\end{array}$ & 0.92 & $0.71-1.20$ & - & - \\
\hline \multicolumn{5}{|l|}{ Type of job } \\
\hline $\begin{array}{l}\text { Healthcare sector } \\
\text { employee versus } \\
\text { other job categories }\end{array}$ & 1.09 & $0.94-1.25$ & - & - \\
\hline \multicolumn{5}{|l|}{ Medical conditions } \\
\hline No medical condition & - & - & - & - \\
\hline $\begin{array}{l}\text { One medical } \\
\text { condition }\end{array}$ & 1.06 & $0.90-1.24$ & - & - \\
\hline $\begin{array}{l}\text { Two medical } \\
\text { conditions }\end{array}$ & 1.23 & $0.90-1.69$ & - & - \\
\hline $\begin{array}{l}\text { Three or more } \\
\text { medical conditions }\end{array}$ & 0.75 & $0.46-1.22$ & & \\
\hline \multicolumn{5}{|l|}{ Risk perception } \\
\hline Low risk perception & - & - & - & - \\
\hline $\begin{array}{l}\text { Medium risk } \\
\text { perception }\end{array}$ & 1.14 & $0.92-1.42$ & 1.10 & $0.88-1.38$ \\
\hline High risk perception & $1.30 *$ & $1.06-1.60$ & 1.18 & $0.95-1.47$ \\
\hline \multicolumn{5}{|l|}{ COVID-19 diagnosis } \\
\hline No diagnosis & - & - & - & - \\
\hline Not sure & 1.05 & $0.65-1.68$ & 1.01 & $0.62-1.63$ \\
\hline Yes - no symptoms & 1.02 & $0.81-1.29$ & 0.89 & $0.69-1.13$ \\
\hline Yes - mild symptoms & 1.13 & $0.89-1.43$ & 1.02 & $0.80-1.29$ \\
\hline $\begin{array}{l}\text { Yes - severe } \\
\text { symptoms }\end{array}$ & $1.42 *$ & $1.01-1.99$ & 1.27 & $0.90-1.79$ \\
\hline $\begin{array}{l}\text { Experience of unfair } \\
\text { treatment }\end{array}$ & & & & \\
\hline
\end{tabular}


medRxiv preprint doi: https://doi.org/10.1101/2021.01.12.21249152; this version posted January 13, 2021. The copyright holder for this preprint (which was not certified by peer review) is the author/funder, who has granted medRxiv a license to display the preprint in perpetuity.

All rights reserved. No reuse allowed without permission.

\begin{tabular}{|l|l|l|l|l|}
\hline $\begin{array}{l}\text { Attributed to any of } \\
\text { the following } \\
\text { reasons: race, } \\
\text { religion, gender or } \\
\text { sexual orientation }\end{array}$ & $1.19^{*}$ & $1.03-1.37$ & 0.97 & $0.82-1.16$ \\
\hline $\begin{array}{l}\text { Race was the only } \\
\text { reason or one of the } \\
\text { reasons }\end{array}$ & $1.30^{* *}$ & $1.12-1.50$ & $1.21^{*}$ & $1.01-1.45$ \\
\hline $\begin{array}{l}\text { Religion was the only } \\
\text { reason or one of the } \\
\text { reasons }\end{array}$ & 1.21 & $0.98-1.49$ & - & - \\
\hline $\begin{array}{l}\text { Gender was the only } \\
\text { reason or one of the } \\
\text { reasons }\end{array}$ & 0.97 & $0.83-1.14$ & - & - \\
\hline $\begin{array}{l}\text { Sexual orientation } \\
\text { was the only reason } \\
\text { or one of the reasons }\end{array}$ & 0.97 & $0.80-1.19$ & - & - \\
\hline
\end{tabular}

$* P<0.05$

$* * P<0.001$

Figure 1. Racial discrimination by type of experience and race 
medRxiv preprint doi: https://doi.org/10.1101/2021.01.12.21249152; this version posted January 13, 2021. The copyright holder for this preprint (which was not certified by peer review) is the author/funder, who has granted medRxiv a license to display the preprint in perpetuity.

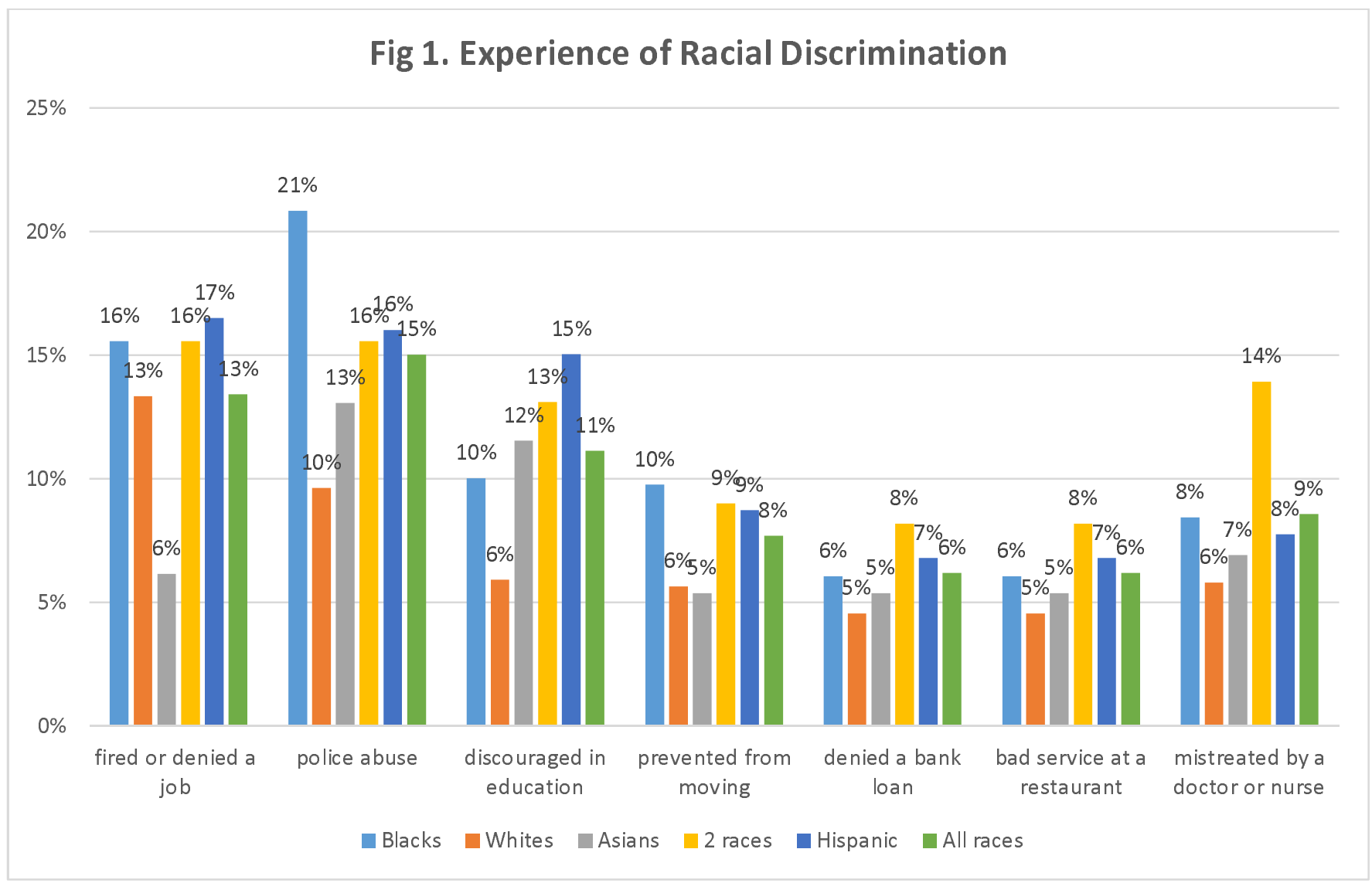

\section{References}

\footnotetext{
${ }^{1}$ Fact Sheet: Explaining Operation Warp Speed. Available at: https://www.hhs.gov/coronavirus/explainingoperation-warp-speed/index.html. Accessed on January 112021.

${ }^{2}$ Pfizer and BioNTech announce vaccine candidate against COVID_19 achieved success in first interim analysis from phase 3 study. Press release. November 9 2020. Available at: https://www.pfizer.com/news/press-release/pressrelease-detail/pfizer-and-biontech-announce-vaccine-candidate-against. Accessed on January 82021.

${ }^{3}$ Moderna Announces Primary Efficacy Analysis in Phase 3 COVE Study for Its COVID-19 Vaccine Candidate and Filing Today with U.S. FDA for Emergency Use Authorization. Press release. November 30 2020. Available at: https://investors.modernatx.com/news-releases/news-release-details/moderna-announces-primary-efficacyanalysis-phase-3-cove-study. Accessed on January $8^{\text {th }} 2021$.

${ }^{4}$ FDA Takes Key Action in Fight Against COVID-19 by Issuing Emergency Use Authorization for First COVID-19 Vaccine. Press release. December 11 2020. Available at: https://www.fda.gov/news-events/pressannouncements/fda-takes-key-action-fight-against-covid-19-issuing-emergency-use-authorization-first-covid-19. Accessed on January 82021.
} 
medRxiv preprint doi: https://doi.org/10.1101/2021.01.12.21249152; this version posted January 13, 2021. The copyright holder for this preprint (which was not certified by peer review) is the author/funder, who has granted medRxiv a license to display the preprint in perpetuity.

All rights reserved. No reuse allowed without permission.

\begin{abstract}
${ }^{5}$ FDA Takes Additional Action in Fight Against COVID-19 By Issuing Emergency Use Authorization for Second COVID-19 Vaccine. Press release. December 18 2020. Available at https://www.fda.gov/news-events/pressannouncements/fda-takes-additional-action-fight-against-covid-19-issuing-emergency-use-authorization-secondcovid. Accessed on January 82021.
\end{abstract}

${ }^{6}$ COVID-19 Vaccination Program Interim Playbook for Jurisdictional Operations. CDC. October 292020 version 2.0 Available at: https://www.cdc.gov/vaccines/imz-managers/downloads/COVID-19-Vaccination-ProgramInterim_Playbook.pdf. Accessed on January 112021.

7 Malik AA, McFadden SM, Elharake J, Omer SB. Determinants of COVID-19 vaccine acceptance in the US. EClinicalMedicine. 2020 Sep;26:100495. doi: 10.1016/j.eclinm.2020.100495. Epub 2020 Aug 12. PMID: 32838242; PMCID: PMC7423333.

${ }^{8}$ Kreps S, Prasad S, Brownstein JS, et al. Factors associated with US adults' likelihood of accepting COVID-19 vaccination. JAMA Netw Open. 2020;3(10):e2025594. doi:10.1001/jamanetworkopen.2020.25594

${ }^{9}$ Malik AA, McFadden SM, Elharake J, Omer SB. Determinants of COVID-19 vaccine acceptance in the US. EClinicalMedicine. 2020 Sep;26:100495. doi: 10.1016/j.eclinm.2020.100495. Epub 2020 Aug 12. PMID: 32838242; PMCID: PMC7423333.

${ }^{10}$ Szilagyi PG, Thomas K, Shah MD, et al. National Trends in the US Public's Likelihood of Getting a COVID-19 Vaccine-April 1 to December 8, 2020. JAMA. Published online December 29, 2020. doi:10.1001/jama.2020.26419

${ }^{11}$ KFF COVID-19 Vaccine Monitor. Hamel L., Kirzinger A., Munana C., Brodie M. Press release. December 2020. Available at: https://www.kff.org/coronavirus-covid-19/report/kff-covid-19-vaccine-monitor-december2020/?utm_campaign=KFF-2020-polling-surveys\&utm_medium=email\&_hsmi=2\&_hsenc=p2ANqtz9EpdM8wscJHy_FjpP9PJ67CUSXfk4f_VyZdVC652V5zly4qBzDeO0b5iDXeDertNU8W0VOp6xcGENIKJvugasI_0OA\&utm_content=2\&utm_source=hs_email. Accessed on January 8 2021.

${ }^{12}$ Quinn SC, Jamison A, Freimuth VS, An J, Hancock GR, Musa D. Exploring racial influences on flu vaccine attitudes and behavior: Results of a national survey of White and African American adults. Vaccine. 2017;35:1167-1174. https://doi.org/10.1016/j.vaccine.2016.12.046.

${ }^{13}$ Centers for Disease Control and Prevention. Flu Vaccination Coverage, United States, 2015-2016 Influenza Season. 2016 https://www.cdc.gov/flu/fluvaxview/coverage-1516estimates.htm.

${ }^{14}$ Bleser WK, Miranda PY, Jean-Jacques M. Racial/Ethnic Disparities in Influenza Vaccination of Chronically III US Adults: The Mediating Role of Perceived Discrimination in Health Care. Medical Care. 2016;54:570-7. https://doi.org/10.1097/MLR.0000000000000544.

${ }^{15}$ Racial Disparities in Flu Vaccination: Implications for COVID-19 Vaccination Efforts. Artiga S., Michaud J., Kates J., Orgera K. Available at: https://www.kff.org/policy-watch/racial-disparities-flu-vaccination-implications-covid-19vaccination-efforts/. Accessed on January 82021.

${ }^{16}$ Dooling K, Marin M, Wallace M, et al. The Advisory Committee on Immunization Practices' Updated Interim Recommendation for Allocation of COVID-19 Vaccine - United States, December 2020. MMWR Morb Mortal Wkly Rep 2021;69:1657-1660. DOI: http://dx.doi.org/10.15585/mmwr.mm695152e2external icon.

${ }^{17}$ Sternthal, M.J., Slopen, N., Williams, D.R. "Racial Disparities in Health.” Du Bois Review: Social Science Research on Race, 2011; 8: 95-113. 
medRxiv preprint doi: https://doi.org/10.1101/2021.01.12.21249152; this version posted January 13, 2021. The copyright holder for this preprint (which was not certified by peer review) is the author/funder, who has granted medRxiv a license to display the preprint in perpetuity. All rights reserved. No reuse allowed without permission.

${ }^{18}$ Public Health Emergency Preparedness and Response Capabilities. Centers for Disease Control and Prevention. October 2018. Updated January 2019. Available at:

https://www.cdc.gov/cpr/readiness/00_docs/CDC_PreparednesResponseCapabilities_October2018_Final_508.pdf. Accessed on January 112021.

${ }^{19}$ Taylor-Clark K, Viswanath K, Blendon R: Communication inequalities during Public Health disasters: Katrina's wake. Health Commun. 2010, 25 (3): 221-229. 10.1080/10410231003698895.

${ }^{20}$ Lin L, Savoia E, Agboola F, Viswanath K. What have we learned about communication inequalities during the H1N1 pandemic: a systematic review of the literature. BMC Public Health. 2014 May 21;14:484. doi:

10.1186/1471-2458-14-484. PMID: 24884634; PMCID: PMC4048599.

${ }^{21}$ Savoia E, Testa MA, Viswanath K: Predictors of knowledge of H1N1 infection and transmission in the U.S. population. BMC Public Health. 2012, 12: 328-10.1186/1471-2458-12-328.

${ }^{22}$ Blendon RJ, Benson JM, Desroches CM, Weldon KJ: Using opinion surveys to track the public's response to a bioterrorist attack. J Health Commun. 2003, 8 (Suppl 1): 83-92. discussion 148-151 